\title{
Evropski upravni prostor - realnost ali mit
}

\author{
UDK: 329 : (490.10): $341 \mathrm{EU}$ \\ Polonca Kovač \\ Fakulteta za upravo \\ polona.kovac@fu.uni-lj.si
}

\section{IZVLEČEK}

Evropski upravni prostor je skupek standardov, ki so se konec devetdesetih let 20. stoletja zaradi potreb širitve Evropske unije razvili kot neformalni acquis communautaire na področju javne uprave. Predmet Evropskega upravnega prostora so reforme glede kakovosti v upravi, e-uprave, sistema javnih uslužbencev, javnih financ, lokalne uprave, paradržavnih organizacij idr. Slovenija je na teh področjih načela zanesljivosti, predvidIjivosti, odprtosti, odgovornosti, učinkovitosti in uspešnosti upoštevala že z vidika izpolnitve političnega merila za polnopravno članstvo v EU. Če presojamo udejanjanje evropeizacije javnih uprav posameznih držav, pa ugotavljamo, da načela Evropskega upravnega prostora v veliki meri niso zaživela v praksi. Drugače velja za upravljanje kakovosti v upravi, kjer do konvergence ukrepov in učinkov prihaja predvsem $z$ uporabo modela Skupnega ocenjevalnega okvira za organizacije $v$ javnem sektorju (CAF).

Ključne besede: evropski upravni prostor, kakovost $v$ javnem sektorju, javni uslužbenci, informatizacija javne uprave, evropski upravni prostor in slovenska uprava

\section{Opredelitev evropskega upravnega prostora}

\subsection{Nastanek in bistveni elementi Evropskega upravnega prostora}

Evropski upravni prostor (angl. European Administrative Space, v nadaljevanju: EUP) je virtualne narave; je metafora, ki ima praktične posledice za države članice EU in države kandidatke.

Bistvo EUP je nabor temeljnih načel in minimalnih standardov, ki glede na neobstoj pravnega reda Evropskih skupnosti (acquis communautaire, $v$ nadaljevanju: acquis) na področju javne uprave določajo delo upravnih organizacij širom po Evropi s temeljnim ciljem učinkovitega izvajanja acquisa'. EUP izhaja iz predpostavke,

1 Učinkovito izvajanje acquisa je pogoj za dejansko funkcioniranje Evropske unije, zato je nujno merilo za presojo kandidatur potencialnih novih članic in hkrati odškodninska osnova za države članice. Področje javne uprave ni predmet primarne zakonodaje, je pa nekaj z upravo povezanih institutov urejenih v sekundarni zakonodaji. 


\section{Evropski upravni prostor - realnost ali mit}

da se $v$ današnjem času delovanje javnih uprav posameznih držav zbližuje do te mere, da govorimo o skupnih vrednotah in posledično o skupnih izhodiščih za upravne strukture, postopke in upravljavske pristope.

Ideja je privlačna, saj predstavlja nadgradnjo klasičnega pojmovanja o zaprtosti javnih uprav posameznih držav, ki so ena od druge neodvisne, ker pač izhajajo iz specifičnih zgodovinskih okoliščin in državnega pravnega reda ${ }^{2}$. Hkrati je veljalo, da predstavlja javna uprava instrument vladajoče koalicije, ki je zopet individualno pogojena na ravni posameznih držav. Kljub premikom sodobnega pojmovanja in delovanja uprave se postavlja vprašanje, ali je ideologija politične, ekonomske in vsesplošne evropske enotnosti možna tudi $v$ tem segmentu. Vsekakor je treba priznati, da prizadevanja $\vee$ to smer obstajajo, kažejo se predvsem $\vee$ obliki sodne prakse Sodišča Evropskih skupnosti (angl. European Court of Justice, v nadaljevanju: SES), stalnih srečanj in izmenjave mnenj ter izkušenj upravnih praktikov in nacionalnih politikov, sodelovanja $v$ mednarodnih organizacijah ${ }^{\mathbf{3}}$, skupnih modelov ${ }^{\mathbf{4}} \mathrm{idr}$.

Načela in zahteve EUP je zaradi potreb širitvenega procesa Evropskih skupnosti uveljavila skupina strokovnjakov v okviru programa SIGMA kot skupne iniciative OECD in programa Phare ${ }^{\mathbf{5}}$ ter jih objavila v več publikacijah, med katerimi sta ključni $\checkmark$ letih 1998 in 1999 izdani »Preparing Public Administrations for the European Administrative Space « in »European Principles for Public Administration«. Druga publikacija skuša dodati praktičnim vidikom združevanja načinov upravljanja, opisanim $v$ prvem delu, teoretično podstat skupnih načel evropskega upravnega prava.

$2 \mathrm{~V}$ evropskem prostoru je glede pravnega reda ključna razlika med anglosaksonskim in kontinentalnim sistemom, ki je kljub zbliževanju posameznih elementov sistemov še vedno aktualna (morda še bolj kot na papirju v mentaliteti uradnikov, politikov in uporabnikov javnih storitev).

3 Poleg evropskih zvez velja poudariti vlogo delovnih skupin, ki delujejo pod krovom OECD PUMA (Public Management), v katerih je status opazovalke februarja 2003 pridobila tudi Slovenija (Working Party on Human Resources Management, Working Party on Regulatory Management and Reform, Senior Officials from Centers of Government, Working Group on Strengthening Government-Citizen Connections).

4 Zlasti gre za modele kakovosti oz. odličnosti v javnem sektorju, kot sta model odličnosti EFOM in Skupni ocenjevalni okvir za organizacije v javnem sektorju - CAF (Common Assessment Framework), več v nadaljevanju.

5 SIGMA (angl. Support for Improvement in Governance and Management in Central and Eastern European Countries) je bila leta 1992 oblikovana za podporo modernizacije upravljanja v srednje in vzhodno-evropskih trancizicijskih državah (med njimi Slovenija). Svoje delo glede na zaključene procese vključevanja teh držav v EU zaključuje, zadnja pogodba se bo iztekla 31. 12. 2003. Sodelovanje med strokovnjaki SIGMA in Slovenijo je bilo zlasti od leta 1999 dokaj konstruktivno, predvsem na področjih sistema javnih uslužbencev (vključno z usposabljanjem), notranje revizije, odpravljanja administrativnih ovir in ustanavljanja paradržavnih javnih agencij. Sodelovanje je potekalo $v$ obliki svetovanja, študij, primerjalno-pravnih pregledov in letnih t. i. strokovnih pregledov (angl. peer reviews), ki so bili med drugim podlaga za letno poročilo Evropske komisije o napredku Slovenije. 


\section{Polonca Kovač}

\section{Evropski upravni prostor - realnost ali mit}

Ta načela naj bi predstavljala t. i. neformalni acquis, ki prvenstveno izhaja iz jurisdikcije SES ${ }^{6}$.

Elementi EUP so za državne pravne rede in javne uprave posameznih držav neobvezni kot taki, vendar so na ravni držav vkorporirani tako ali drugače, saj gre za načela občega prava in nauke skupnega zgodovinskega, političnega in upravnega razvoja. Dodatno je treba poudariti, da so javne uprave po vsem svetu, skupaj z izvoljenimi politiki, upoštevaje sodobne reforme zadnjih dvajsetih let, poleg kogentnega prava dolžne za legitimnost in $s$ tem lastno kontinuiteto upoštevati tudi zahteve in pričakovanja odjemalcev javnih storitev (angl. stakeholders). Kljub navedenemu pri EUP neposredno ne prihaja do vprašanja posega v koncept državne suverenosti ${ }^{7}$.

EUP sugerira prvenstveno naslednje cilje in sektorske politike (SIGMA, 1998, str. 112-116):

1. glede političnih institucij:

1.1. svobodne volitve,

1.2. načelo delitve oblasti in medsebojnega nadzora,

1.3. vsaj minimalna lokalna samouprava in avtonomija,

1.4. varstvo političnih in državljanskih pravic, varstvo manjšin;

2. glede javne uprave ${ }^{8}$ :

2.1. neodvisnost javne uprave od politike,

2.2. jasnejša ureditev izvajanja javnih služb,

2.3. sodoben sistem javnih uslužbencev, ki naj bo urejen $v$ krovnem zakonu in naj temelji na kariernem sistemu,

2.4. specializirano, ciljno usposabljanje (še posebej glede evropskih zadev) in učenje prek praktičnega dela in izkušenj (angl. learning by doing, learning from experience),

2.5. primerljivost plač v zasebnem in javnem sektorju,

2.6. strukturirano zaposlovanje in prerazporejanje prek interne mobilnosti;

3. glede reforme javne uprave:

3.1. jasen načrt reforme (lahko poseben organ kot skrbnik za implementacijo načrta):

4. glede centralne (državne) uprave:

4.1. medministrska koordinacija9.

6 Weiler (2003, str. 347 in nasl.) poudarja, da tudi SES ne odloča popolnoma apolitično (kar bi bilo nenazadnje neživljenjsko), zato je moč iz judikature povleči več podlag za EUP, kot bi jih bilo sicer. Ta načela so po SIGMA (1998), Ivanc (2003), Bugarič (2003, str. 28) sorazmernost, zaupanje v pravo, pravna določnost, antidiskriminacija, zaslišanje $v$ upravnih postopkih, začasno pravno varstvo, nepogodbena odgovornost javne uprave itd.

7 Državna suverenost sama po sebi že dolgo ni več nedotakljiva, saj vanjo posegajo temeljni akti ES in EU, vzporedno tudi ustave držav. To velja tudi za zadnjo revizijo slovenske ustave v letu 2003 (3.a člen). Več v Ivanc (2003). Weiler v zvezi s tem govori o t. i. "poddržavnosti« (2003, str. 134 in nasl., posebej o komitologiji kot instrumentu poddržavnosti str. 374 in nasl.).

8 EUP (niti acquis) ne vsebuje zahtev glede organizacije državnih uprav, tako je zlasti odločitev o številu in nalogah resorjev stvar držav samih. Področje javne uprave (kot primer) je umeščeno v nekaterih državah $v$ Ministrstvo za notranje zadeve, $v$ nekaterih $v$ Ministrstvo za finance, ponekod imajo samostojno Ministrstvo za upravo.

9 Posebej primerjalna študija poudarja potrebo po večji koordinaciji znotraj državne uprave ravno za Slovenijo (1998, str. 116). 


\section{Evropski upravni prostor - realnost ali mit}

Leta 1999 opredeljena evropska načela za javno upravo (SIGMA, 1999, str. 8 in nasl.) izhajajo iz načel občega upravnega prava in so združena $v$ štiri skupine:

1. zanesljivost in predvidljivost (pravna varnost), ki temeljita na zakonitosti in nepristranskosti,

2. odprtost in transparentnost,

3. odgovornost in

4. učinkovitost (gospodarnost pri uporabi javnih virov) in uspešnost (doseganje ciljev javnih politik, primarno določenih $v$ zakonodajii ${ }^{\mathbf{1 0}}$.

Podrobneje načelo zanesljivosti in predvidljivosti določajo podnačela vladavine prava oz. pravne države (s poudarkom na nevtralnosti, antidiskrimanciji, hierarhiji pravnih aktov, nadzoru uprave s strani neodvisnih sodišč), pristojnosti in odgovornosti, odločanja po diskreciji, sorazmernosti, postopkovne pravičnosti, pravočasnega reševanja zadev, nepristranskosti in profesionalizma.

Odprtost in transparentnost sta pogoj za zunanji nadzor in spoštovanje drugih načel, zlasti vladavine prava, enakosti pred zakonom in odgovornosti. Edini dovoljeni izjemi sta nacionalna varnost in varstvo osebnih podatkov. $V$ upravnih postopkih se to načelo izraža v predpisani obrazložitvi odločitve, kar onemogoča malomarno in koruptivno reševanje in je podlaga za pritožbeno odločanje.

Odgovornost je opredeljena ob predpogoju ustreznih pristojnosti oz. pooblastil kot zaveza drugemu upravnemu, zakonodajnemu ali sodnemu organu obrazložiti in upravičiti svoje ravnanje in odločitve. Odgovornost je bistvena za zagotavljanje učinkovitosti, uspešnosti, zanesljivosti in predvidljivosti javne uprave. $\vee$ upravi je predpisana že s formalnimi upravnimi in drugimi postopki.

Učinkovitost in uspešnost je relativno nova kategorija, ki je postala dimenzija uprave primarno na temelju fiskalnih omejitev državnih proračunov. Učinkovitost se sicer ne nanaša le na javne finance, temveč na vse uporabljene vire, uslužbence, IT, nepremičnine in opremo itd. ${ }^{11}$ Uspešnost stremi $k$ evalvaciji javnih politik, saj pomeni doseganje ciljev in reševanje javnih problemov, opredeljenih kot takih $v$ zakonih. Tako imenovana načela $5 E$ (vsa se v angleščini začenjajo s črko "e«), to so učinkovitost, uspešnost, ekonomičnost, etičnost in varovanje okolja (angl. environment), so ob vladavini prava vrhovna merila za presojo javnih uprav ter dejavnosti in odločitev javnih uslužbencev. Potencialni konflikt med učinkovitostjo ter vladavino prava in zakonitostjo na drugi strani se naj razreši prek ločitve usmerjevalnih in izvajalskih funkcij uprave, tako da uprava določa javne politike in vrši nadzor, medtem ko samo izvajanje prenese na pogodbene izvajalce (angl. contracting-out).

$10 \mathrm{~V}$ angleščini: reliability and predictability (legal certainty), openness and transparency, accountability, efficiency and effectiveness.

11 Sodobna teorija upravljanja šteje od nedavnega kot enega ključnih virov poleg naštetih "znanje» in govori o samostojni veji upravljanja znanja. Ta kategorija je med drugim izrecno zajeta v modelu CAF. 
Polonca Kovač

Evropski upravni prostor - realnost ali mit

\subsection{Alternativni in kritični pogledi na EUP}

Pri opredelitvi EUP moramo takoj na začetku opozoriti, da se vzporedno z navdušenjem nad dejanskostjo in nadaljnjimi možnostmi evropeizacije javnih uprav pojavlja velika mera skepticizma $\vee$ gornje ideje, tako na strani akademikov kot praktikov. (Na temo EUP je bilo organiziranih nekaj specialnih konferenc, npr. septembra 2002 v Potsdamu, ki že z opredelitvijo nosilnih tematik posveta nakazujejo določeno problematičnost enotnega pojmovanja EUP, npr. »The European Administrative Space: convergence or divergence?«.)

Odprtih je nekaj osnovnih vprašanj:

1. Kaj je javni sektor in kaj je javna uprava? Glede na delegacijo nekaterih nalog iz ožje državne uprave $v$ širši javni sektor ali celo izven njega, decentralizacijo $v$ razmerju med državno upravo in lokalno samoupravo, pojav javno-zasebnega partnerstva (angl. Public-Private-Partnership) ipd. se postavlja nepremostljiv problem že pri definiciji osnovnih pojmov ${ }^{\mathbf{1 2}}$, čeprav skušajo to dilemo strokovnjaki premostiti z izrecno zavezanostjo načel EUP in judikature SES ne samo na organe državne uprave, temveč tudi razne paradržavne organizacije.

2. Kje so meje EUP - ali gre za vezanost na države članice EU, so vključene države pristopnice oz. kandidatke, gre za članice Sveta Evrope ali se EUP nanaša na meje geografske Evrope ali kaj petega? Večina avtorjev glede na podstat EUP, to je učinkovito izvrševanje acquisa, in pristojnost SES kot oblikovalca sodne prakse evropskih načel upravnega prava, to je na ozemlju držav članic EU, zagovarja ožje tolmačenje - EUP se razteza nad teritorijem članic EU, njenih pristopnic ter kandidatk ${ }^{\mathbf{1 3}}$.

3. Ali se EUP veže na javno upravo ali na upravno pravo ali na oboje ${ }^{\mathbf{1 4}}$ ?

4. Ali lahko govorimo o že uveljavljenem EUP, torej o realnosti evropeizacije javnih uprav?

12 Strategija nadaljnjega razvoja slovenskega javnega sektorja 2003-2005 opredeljuje javni sektor v skladu z definicijo Zakona o javnih uslužbencih in Zakona o sistemu plač v javnem sektorju (oba Uradni list RS, št. 56/02) kot celoto državnih organov in uprav samoupravnih lokalnih skupnosti, javnih agencij, javnih skladov, javnih zavodov in javnih gospodarskih zavodov ter drugih oseb javnega prava, če so posredni uporabniki državnega proračuna ali proračuna lokalne skupnosti; dodana so še javna podjetja kot izvajalci javnih služb na področju gospodarske infrastrukture.

13 Tako kot z izrazom Evropa včasih mislimo le EU, se v pogovornem, žal pa tudi v strokovnem jeziku nejasno uporablja pojem Amerika, ko so mišljene le Združene države Amerike. Tem nedoslednostim bi se morali čim bolj izogibati, saj vnašajo zmedo $v$ osnovne pojme. $V$ okviru obravnavanega je to še posebej pomembno, če gre za pravna učinkovanja, ko nejasnost subjekta ali objekta lahko zaradi pravil o pristojnosti in stvarni legitimaciji povzroči ničnost odločanja ali izgubo prekluzivnih pravic.

14 Več o teoretičnih in praktičnih vidikih evropskega upravnega prava ter o EUP z zornega kota upravno-pravne znanosti Ivanc (2003), tudi Bugarič (2003, str. 25-26). 
Dejstvo je, da "evropska javna uprava" kot enotni pojem in praksa ne obstaja. Javne uprave posameznih evropskih držav (članic EU ali ne) delujejo v lastnih pravnih in političnih okvirih, ki različno definirajo obseg javnega sektorja in javne uprave, naloge uprave, upravne organe, upravne postopke in druge poslovne procese $v$ upravi, sistem javnih uslužbencev in njegove elemente, sistem javnih financ idr. Nenazadnje ne moremo govoriti o "evropskem uporabniku javnih storitev, saj glede na različne izvajalce-ponudnike ni enotnega povpraševalca (kar pa zaradi pojava globalizacije ni izključeno v naslednjih desetletjih). Kot pravi Ivanc (2003): "Sploh pa je vprašljivo, ali je zbliževanje javnih uprav $\vee$ Evropi toliko pogojeno z razvojem evropskega upravnega prava, kolikor to predpostavljajo številni upravni in upravnopravni teoretiki.«; enak skepticizem izraža Engel (2003) ${ }^{\mathbf{1 5}}$. Med pravnimi in dejanskimi (lahko bi rekli celo moralnimi) posledicami evropske integracije velja na tem mestu izpostaviti, da se članice zavestno odrekajo delu svoje državne suverenosti. Nadalje je zelo zanimivo vprašanje razmerij med vejami oblasti, saj je glede na strukturo in funkcionalna razmerja med institucijami EU zaslediti čedalje večjo moč izvršilne veje oblasti na račun slabenja vloge parlamenta (več v Weiler, 2002, npr. str. 97, 111 in nasl.). Bugarič (2003, str. 25) s tem v zvezi pojasnjuje označbo uprave kot četrtega nevidnega stebra EU (ob bok trem stebrom iz Evropske pogodbe). Odpirajo se nove dimenzije načela delitve oblasti, upoštevaje, da se sodobne regulatorne in druge upravne reforme med drugim osredotočajo na oženje klasične državne uprave s prenosom njenih nalog na subjekte (kvazi)javnega in zasebnega sektorja. Po mnenju Flynna, Strehla (1996, str. 269) in Falconerja (1997) je kljub različnim vzrokom za reforme skupni imenovalec evropskih (Švedska, Velika Britanija, Nemčija, Nizozemska, Francija, Avstrija in Švica) upravnih reform v zadnjih dveh desetletjih $v$ spremenjeni paradigmi uprave $z$ nalogami managementa rezultatov.

Ob tem naj opozorimo na nekaj dodatnih sodobnih pojavov $v$ upravi, ki vnašajo $\checkmark$ pojmovanje in razumevanje EUP določene dvome. Tako je npr. značilnost modernega sistema javnih uslužbencev, da ne določa le delovnopravnih vidikov razmerij med državo/lokalno skupnostjo in zaposlenimi, temveč vključuje čedalje več elementov menedžmenta, zlasti za uradnike na najvišjih položajih, čemur se standardi EUP bolj kot ne izogibajo.

Nadalje je treba pod drobnogled vzeti pojem javnega upravljanja kot ključnega elementa družbenega razvoja, pri čemer so (še) nerazrešena razmerja do neupravnih družbenih podsistemov. Doktrina dobrega upravljanja (angl. good governance), ki jo je razvila OECD, pravi, da je javno upravljanje skupaj z gospodarskim razvojem in socialno kohezijo pogoj za trajen družbeni napredek. Doktrino nadalje razgrajuje dokument Evropske komisije "White Paper on Governance», ki določa naslednja

15 Engel se tako izrazi pravzaprav med vrsticami, ko ob navajanju skupnih značilnosti strategij upravljanja kakovosti v državah kandidatkah elegantno doda: "This is not to say that the author supports the suggestion of the emergence of a European Administrative Space." 
Polonca Kovač

Evropski upravni prostor - realnost ali mit

temeljna načela dobrega upravljanja: odprtost, sodelovanje, odgovornost, učinkovitost in koherentnost.

Upoštevaje skupna izhodišča evropskega razvoja nekateri avtorji poudarjajo, da EUP ni edina alternativa teh stičišč. Med drugim je bila oblikovana ideja o Evropski upravni skupnosti (angl. European Administrative Community, več Ivanc (2003) in Bugarič (2003)), ki naj bi posamezne učinke poenotenja $v$ državah članicah EU razvijala kot nadgradnjo nacionalnih tradicionalnih upravnih sistemov in načinov upravnega delovanja.

Ob tem se pojavlja še vprašanje relacije med EUP in novim javnim menedžmentom (angl. New Public Management). Novi javni menedžment se je kot nova paradigma javnega upravljanja, ki v javni sektor prenaša s ciljem večje učinkovitosti in demokratičnosti nekatere principe in metode zasebnega sektorja, pojavil od konca osemdesetih let prejšnjega stoletja, sprva $v$ anglosaksonskem prostoru, nato po vsem svetu. Ob klasičnih vrednotah uprave sugerira nadgradnjo z načeli usmerjenosti k strankam, učinkovitosti, decentralizacije, privatizacije itd. Koncepti novega javnega menedžmenta se z načeli in standardi EUP prekrivajo, morda je le pri slednjem opaziti manj usmerjenosti $\vee$ golo učinkovitost, racionalizacijo in javnofinančne reforme. S političnega vidika pa je neizpodbitno, da je EUP instrument Evropske unije, medtem ko je novi javni menedžment idejna zasnova, nevezana na konkretno državo ali meddržavno zvezo.

\section{Poglavitna področja evropskega upravnega prostora}

\subsection{Kakovost $v$ javnem sektorju}

Temeljno vprašanje pri spodbujanju in razvoju kakovosti $v$ javni upravi je stopnjevanje njene legitimnosti. Le uprava, ki upošteva zahteve in pričakovanja njenih uporabnikov, seveda $\vee$ primer konflikta javnega in individualnih interesov podrejeno prvemu, je $v$ času in prostoru demokratična in legitimna ${ }^{16}$. Definicija kakovosti pa je ravno ujemanje potreb uporabnikov storitev in njihove ponudbe oz. načina izvajanja. Upravljanje kakovosti in razvoj odličnosti v upravi sledita temeljnim evropskim načelom odgovornosti in učinkovitosti ter uspešnosti.

Za razvoj TQM (angl. Total Quality Management, celovito obvladovanje kakovosti) je značilno, da direktnega vpliva evropske integracije ni, medtem ko je izjemno močan v posredni obliki. Nekatere države (npr. Estonija) se pri oblikovanju nacionalnih strategij zaradi aktualnosti globalnih ukrepov, a pomanjkanja

16 Legitimna uprava naj bi bila kljub večji odprtosti in s tem manj možnostim sledenja parcialnim interesom tudi $v$ interesu politikov, katerih verjetnost ponovne izvolitve je po ekonomski teoriji pogojena s stopnjo zaupanja v oblast (Ferfila, 2002). 


\section{Evropski upravni prostor - realnost ali mit}

acquisa, sklicujejo celo neposredno na EUP. Engel (2003) na več mestih ugotavlja, da je šel vpliv EUP in dobrih praks $\vee$ članicah EU tako daleč, da je za kandidatke postala primerljivost z EU dodatno merilo, posebej glede zahteve, da mora uprava nuditi podporo gospodarskemu in socialnemu razvoju in konkurenci. Temu razlogu pripisuje velik razmah uporabe evropskih standardov kakovosti (ISO, EFOM, CAF) v državah kandidatkah oz. pristopnicah.

H globalizaciji kakovosti $v$ upravi $v$ evropskem merilu je veliko doprineslo Evropsko omrežje za javno upravo (angl. European Public Administration Network, EPAN), ki ga na treh osnovnih ravneh sestavljajo ministri za javno upravo $v$ članicah $E U$, generalni direktorji in slednjič višji uradniki $\vee$ štirih delovnih skupinah, to so Innovative Public Services Group (IPSG), Human Resource Management Group, E-government Group in Better Regulation Group. Skupina IPSG se ukvarja s kakovostjo $v$ upravi kot vseobsežnem elementu odnosa med upravo in uporabniki njenih storitev. $\vee$ zadnjih petih letih delovanja se je skupina posvečala predvsem razvoju Skupnega ocenjevalnega okvira za organizacije $v$ javnem sektorju (CAF), organizaciji konferenc o kakovosti $v$ evropskih javnih upravah in instrumentom za primerjanje (angl. benchmarking).

Model CAF je bil oblikovan $v$ letih 1998-2000 na osnovi modela odličnosti EFQM, vendar je njegova bistvena dodana vrednost upoštevanje specifik organizacij $\vee$ javnem sektorju, med katerimi so izpostavljene vpliv politike na delo, procesni način dela, usmerjenost k uporabnikom in nefinančni rezultati uspešnosti delovanja. Model je oblikovan $v$ obliki vprašalnika, ki ni pretirano zahteven, njegov osnovni namen je analizirati uspešnost in učinkovitost organizacije po vseh elementih delovanja, da bi identificirali točke, ki jih je treba prednostno izboljšati. CAF je $\vee$ borih dveh letih uporabilo okoli 400 organizacij, med njimi dobra tretjina organov javne uprave, zato je bila oktobra 2002 predstavljena izboljšana različica vprašalnika. Danes je $v$ bazi podatkov Evropskega inštituta za javno upravo približno 200 organizacij javne uprave, od tega 11 slovenskih. Ta baza mora $\vee$ nadaljevanju postati osnova za primerjanje in izmenjavo dobrih praks med uporabniki. Da bi ta cilj pospešili, se je Italija $\vee$ sklopu trenutnega predsedstva odločila novembra 2003 organizirati celo specialno konferenco o CAF na evropski ravni, ki je prvenstveno namenjena razpravi, kako načrtovati ukrepe po opravljeni oceni, da bi upravne organizacije dosegle pri svojem delovanju optimalen učinek za uporabnike, odjemalce, partnerje in družbo nasploh.

IPSG je v letu 2000 s ciljem promocije kakovosti v upravi in izmenjave idej ter izkušenj organizirala 1 . konferenco o kakovosti $\vee$ evropskih javnih upravah $\left(1^{\text {st }}\right.$ Quality Conference - 10C), ki ji je oktobra 2002 sledila 2. konferenca v Kopenhagnu 
Polonca Kovač

Evropski upravni prostor - realnost ali mit

$(2 \mathrm{OC})^{17}$, medtem ko se že zaključujejo priprave na 3. konferenco (30C), ki bo septembra 2004 v Rotterdamu. Konference so oblikovane kot nabor aktualnih tem, pri čemer se področja EUP medsebojno tesno prepletajo (kakovost, upravljanje kadrovskih virov, e-uprava, regulatorne reforme itd.). Konference imajo izjemen odmev $v$ evropskih upravah glede poenotenja idej in ukrepov, ki se jih posamezne uprave lotevajo, kar je nenazadnje njihov izvorni namen.

\subsection{Upravljanje kadrovskih virov v sistemu javnih uslužbencev}

Sistem javnih uslužbencev $\vee$ EU z vidika pravne ureditve ni popolnoma decentralizirano področje, temveč poleg posebnih določb o zaposlenih $\vee$ institucijah EU (angl. staff regulations) pozna nekaj kogentnih pravil, izhajajočih iz več direktiv in uredb, ki se ukvarjajo z vprašanji enakih možnosti oz. antidiskriminacije pri zaposlovanju (zlasti na temelju nacionalnosti), napredovanja, nagrajevanja, prostega pretoka delavcev ${ }^{\mathbf{1 8}}$, socialne varnosti, nostrifikacije spričeval, varnosti in zdravja pri delu, delovnega časa in starševskega dopusta, pogodb o zaposlitvi idr., podrobneje Bosaert in Demmke (2003, str. 81).

Da za zaposlene $v$ upravi obstaja poseben uslužbenski sistem, ki se ga v precejšnji meri dotika EUP, izhaja iz specifičnega dualnega položaja države, ki nastopa na eni strani kot zakonodajalec, na drugi kot delodajalec in prek državnega proračuna financer plač javnih uslužbencev. Posebej se priporoča, da so status, pravice in obveznosti javnih uslužbencev urejeni s posebnim zakonom ${ }^{\mathbf{1 9}}$ in poudarek na načelih strokovnosti, politične nevtralnosti, nepristranskosti in etike uradnikov. Med posameznimi elementi upravljanja kadrov se večjo pozornost posveča usposabljanju, napredovanju, nagrajevanju, razporejanju, upokojevanju in socialni varnosti.

17 Naj informativno podamo podatek o udeležbi na tovrstnih konferencah: z vse Evrope se je lizbonske konference udeležilo prek 1000, kopenhagenske pa kar 1400 udeležencev. Te številke potrjujejo stališča nekaterih, da je ključna sila razvoja EUP pritisk uradnikov samih, ki želijo doseči skupno razumevanje istih pojmov in slediti najboljšim praksam (t. i. "peer pressure«).

Kljub množičnosti se organizatorji srečujejo s problemom, da so vsi udeleženci bolj ali manj javni uslužbenci in da na nek način prepričani prepričujejo prepričane, medtem ko manjkajo (reprezentativni) predstavniki uporabnikov javnih storitev.

18 Izjema od pravila prostega pretoka delovne sile velja za delovna mesta v javnem sektorju, kjer je lahko razpisni pogoj državljanstvo ene od članic EU, kadar gre za izvrševanje pooblastil javnega prava in varovanje splošnih interesov države ali lokalne skupnosti (Zadeva 149/79 Komisija vs. Belgija).

19 Slovenski Zakon o javnih uslužbencih (Uradni list RS, št. 56/02) je temu priporočilu sledil, pri čemer vprašanje plač $v$ javnem sektorju obravnava ločeno $v$ posebnem zakonu. Pri tem je treba poudariti, da je po vsebinski plati konceptualno in konkretno evropskim standardom $v$ veliki meri sledil že "stari« Zakon o delavcih v državnih organih (Uradni list SRS, št. 15/90 in novele). 


\section{Evropski upravni prostor - realnost ali mit}

Svetuje se uvedba (modificiranega) kariernega sistema (s ciljem kontinuitete, stabilnosti, pravne varnosti), primerljivost plač $v$ javnem in zasebnem sektorju, intenzivirano usposabljanje na področju evropskih zadev ${ }^{\mathbf{2 0}}$, premestitve iz naslova racionalne uporabe virov ipd.

Zanimiva je navedba ključnih dolžnosti javnih uslužbencev, kjer SIGMA poudarja zavezo javnih uslužbencev, da ves svoj delovni čas posvetijo službi (možno je le kombiniranje s poučevanjem ali pisanjem), lojalnost državi in instituciji, spoštovanje hierarhije, stalno usposabljanje. Med pravicami zaposlenih izpostavlja enakost, svobodo izražanja mnenja, pravične plače, odpust le zaradi disciplinskih razlogov, nesposobnosti ali strukturnih sprememb idr.

\subsection{Informatizacija javne uprave}

Ukrepi v sklopu e-uprave (angl. e-government) se nanašajo predvsem na notranje poslovanje uprave, kjer stremijo k optimizaciji in standardizaciji postopkov, in na odnos med upravo in uporabniki, kjer naj bi povečali dostopnost in prilagodljivost uprave tako fizičnim kot pravnim osebam. Na evropski ravni je $v$ ta namen ključen dokument Akcijski načrt e-Evropa, ki definira za uporabnike najbolj pomembne upravne storitve (npr. davčni postopki, registracije podjetij itd.), v sklopu katerih naj bi države postopoma razvile informativne, interaktivne in komunikacijske načine poslovanja s strankami.

Ko govorimo o evropeizaciji in globalizaciji, je področje informatizacije s tehnološkega vidika pravzaprav prvo, ki nam pride na misel. Z vidika izvedljivosti bi morala biti informatizacija uprave vodilna dejavnost razvoja, seveda kot sredstvo in ne kot cilj. Poglavitni razlog za obratno prakso je $v$ tem, da informatika kot taka ne more nadomeščati vsebine, lahko jo samo oblikuje $v$ sodobni formi. Zato ne morejo informatiki voditi reforme e-uprave, temveč morajo biti prioritete razvoja, t. j. informatizacija posameznih upravnih storitev, določene predhodno po merilih kompleksnosti, pogostnosti, vpliva na trg ipd.

20 Vlada RS je leta 2000 sprejela posebno strategijo usposabljanja na področju evropskih zadev za posamezne ciljne skupine, $v$ okviru katere ima poseben pomen program intenzivnega usposabljanja za zaposlitev v institucijah EU (angl. Fast Stream). Strategija je bila v pretežni meri realizirana z vidika množične udeležbe, tako je bilo leta 2000 (od septembra) vključenih 600 javnih uslužbencev, v letu 2001 kar 1717, v letu 20021325 in v letu 2003 (do septembra) 640 (od tega je bilo udeležencev programa Fast Stream $v$ treh generacijah 38). Takšno udeležbo je omogočila delna centralizacija finančnih sredstev $v$ ta namen; gre za sprva le 4,5 milijonov tolarjev $v$ letu 2000 , nato pa $v$ okviru samostojne proračunske postavke leta 2001 že 64 milijonov tolarjev, v letih 2002, 2003 in 2004 pa za rang cca 110 milijonov tolarjev. Izvajanje strategije se bo izteklo leta 2005. 
Polonca Kovač

Evropski upravni prostor - realnost ali mit

\subsection{Javne finance}

Na področju javnih financ se večina standardov EUP usmerja v izhodno usmerjenost in $s$ tem proračunsko financiranje, usmerjeno $v$ rezultate (angl. result budgeting), kar mora biti vkorporirano $v$ načrtovanje, izvajanje in evalvacijo proračuna. Posebna pozornost je namenjena interni in eksterni reviziji. Dodatno se EUP ukvarja s finančno koordinacijo oz. usmerjanjem pogodbeno vezanih izvajalcev javnih storitev. Javne finance so na splošno $v$ reformah posameznih držav vse prevečkrat ločene od upravnih reform, kar ne vodi k optimalnemu učinkovanju enih in drugih, zato je treba to prakso preseči. Poudarek pri načrtovanih reformah mora biti na skladnosti javno-finančnih ukrepov s strateškimi cilji uprave in merjenjem uspešnosti (angl. performance measurement) ter končno vrednotenjem uspešnosti zastavljenih javnih politik. SIGMA (1998, str. 162-163) države kandidatke posebej napotuje glede črpanja strukturnih skladov.

\subsection{Lokalna uprava}

Temi, ki jih za lokalno upravo EUP izpostavlja kot specifični (čeprav so sicer lokalne skupnosti del javne uprave nasploh), sta predvsem participacija občanov (soodločanje pri zadevah lokalnega pomena) in decentralizacija državnih nalog na občine in druge lokalne skupnosti. Pri decentralizaciji je treba opozoriti, da je mišljena tako funkcionalno kot fiskalno, več Lavtar v Brezovšek (2003, str. 203217). Notranje naj razvoj v lokalni upravi stremi k profesionalizaciji njenih uslužbencev (SIGMA, 1998, str. 173).

\subsection{Paradržavne organizacije in razvoj pogodbenih razmerij v javnem sektorju}

Delegacija pristojnosti državne uprave paradržavnim organizacijam je poleg decentralizacije funkcionalno-organizacijski izraz demokratičnih standardov EUP. Priporoča se krovni zakon za ureditev skupnih načel delovanja ${ }^{21}$. S tem naj bi bil omogočen prenos izvajalskih (ne pa toliko regulatornih in sploh ne nadzornih) nalog uprave na druge subjekte, kar bi vodilo $v$ manjšo, cenejšo in bolj gibko državno upravo s poudarkom na servisni in ne represivni funkciji. Demokratičnost se izkazuje

21 Slovenski Zakon o javnih agencijah (Uradni list RS, št. 52/02) uresničuje ta princip, pri čemer (skladno s 15. členom zakona o državni upravi) v 4. členu določa, da se javna agencija lahko ustanovi s posebnim zakonom, če je s tem omogočeno učinkovitejše in smotrnejše opravljanje nalog, kot bi bilo $v$ primeru opravljanja nalog $v$ upravnem organu, zlasti če se lahko opravljanje upravnih nalog $v$ celoti ali pretežno financira z upravnimi taksami oz. plačili uporabnikov; ali (alternativno, ne kumulativno!) če glede na naravo oz. vrsto nalog ni potreben ali ni primeren stalen neposredni politični nadzor nad opravljanjem nalog. 


\section{Evropski upravni prostor - realnost ali mit}

s prilagajanjem uporabnikom javnih storitev in večjo avtonomijo delovanja $v$ neodvisnosti od trenutne politične opcije.

\subsection{Drugo}

Poleg navedenih področij se EUP $\vee$ izdaji publikacije SIGMA ukvarja tudi z drugimi temami, npr. z bojem proti korupciji in varstvom potrošnikov (1998, str. 117) ter nekaterimi sektorskimi politikami (1998, str. 113-114, npr. promet, telekomunikacije, okolje, carina).

\section{Evropski upravni prostor in slovenska uprava}

Kot rečeno, je EUP nastal na temelju kandidatur srednje in vzhodno evropskih držav za polnopravno članstvo v ES oz. EU. Evropski svet je v Kopenhagnu (1993), Madridu (1995), Luxemburgu (1997) in Helsinkih (1999) kot enega od treh kriterijev za pristop k EU, ki jih je morala uresničiti država kandidatka za polnopravno članstvo, postavil merilo sposobnosti prevzema obveznosti članstva oz. usposobljenosti za izvrševanje acquisa ${ }^{\mathbf{2 2}}$. Gre za politični kriterij, ki pravi, da morajo imeti države "stabilne institucije, ki zagotavljajo demokracijo, vladavino prava, človekove pravice ter spoštovanje in varstvo manjšin«, pri čemer bo integracija novih držav v EU zahtevala "prilagoditev njihovih upravnih struktur«. Glede na navedeno ne moremo reči, da je EU od kandidatk zahtevala konkretne ukrepe "prilagajanja» oz. modernizacije uprav, vendar je s posameznimi instrumenti, kot je npr. letno redno poročilo o napredku, sugerirala, kaj je bolj in kaj manj všečno ${ }^{\mathbf{2 3}}$. Drug instrument EU nadzora so bili letni SIGMA pregledi (zadnji maja 2003), v okviru katerih se je preverjalo predvsem naslednje: operacionalizacija načela zakonitosti $\vee$ sistemskih zakonih, določbe $v$ delovnopravni zakonodaji glede odgovornosti javnih uslužbencev in dolžnosti njihovega nepristranskega delovanja, vnaprejšnja določenost meril za odločanje $v$ upravnih postopkih in sodni nadzor nad upravo, upravljanje in nadzor javnih skladov (Cardona, 2001). EU se torej ne ukvarja z obliko državne uprave, se pa zelo ukvarja z rezultati njenega delovanja, kot pravi Nizzo v Bugarič $(2003$, str. 27)

22 Pri tem so bili poudarki na posameznih zasedanjih sveta različni, povzeto po Cardona (2001), tako v Kopenhagnu stabilnost institucij, ki naj zagotavlja demokracijo, vladavino prava in varstvo človekovih pravic; $v$ Madridu prilagojenost upravnih in pravosodnih struktur za prenos acquisa in njegovo implementacijo; v Luxemburgu večja moč institucij; v Helsinkih delovanje na podlagi skupnih vrednot in ciljev, kot jih določajo ustanovne pogodbe EU.

23 Predstavniki Evropske komisije so v Sloveniji glede javne uprave povpraševali pravzaprav le po treh stvareh: 1 - kdaj bo sprejet na kariernem sistemu temelječ zakon o javnih uslužbencih, 2 kdaj bo sprejet zakon o javnih agencijah, ki naj bi omogočil privatizacijo, 3 - kako se izvaja nacionalna strategija usposabljanja na področju evropskih zadev. Glede na to je bilo prvo pozitivno poročilo za javno upravo izdano šele leta 2002 po sprejemu reformnih zakonov. 


\section{Polonca Kovač}

\section{Evropski upravni prostor - realnost ali mit}

Oz. je eksplicitno določeno v SIGMA (1998, str. 121) ${ }^{\mathbf{2 4}}$. Poleg reforme slovenske uprave kot političnega merila je bila javna uprava inkorporirana $\vee$ posamezna pogajalska poglavja predvsem z vidika upravnih institucij, ki naj bi bila nosilna za učinkovito delo na določenem upravnem področju ${ }^{\mathbf{2 5}}$. Reforma slovenske javne uprave je vsekakor temeljila na evropskih zahtevah in spodbudah, vendar bi slovenska uprava svoje delovanje reformirala tudi sicer $^{\mathbf{2 6}}$.

Če si ogledamo reformo (razvoj, modernizacijo) slovenske javne uprave pobliže, lahko opredelimo več njenih podfaz. Sprva je reforma slovenske uprave pomenila strokovno podporo vzpostavitvi samostojne države, tako da sta bili ključni nalogi nadaljevanje tekočih upravnih storitev in konstituiranje nekaterih novih, prej zveznih služb (npr. carina). Nadalje je pomemben mejnik politična odločitev za začetek procesa vključevanja RS v ES, ki je bil na strateški ravni dokumentiran s posebnim akcijskim načrtom, katerega del je bil implementacijski načrt za reformo slovenske javne uprave 1997-1999. V naslednjih letih se je razvoj uprave vršil (brez pisne strategije) predvsem na področjih funkcionalne in organizacijske redefinicije uprave, sistema javnih uslužbencev in plač v javnem sektorju, odprave administrativnih ovir, kakovosti $\vee$ upravi, e-uprave, ciljnega usposabljanja idr. $\vee$ to obdobje sodi sprejem vrste temeljnih zakonov s sodobnimi rešitvami, ki so upoštevala standarde EUP in bila večinoma predmet pogajalskih izhodišč, to so Zakon o državni upravi (Uradni list RS, št. 83/03 - uradno prečiščeno besedilo), Zakon o javnih agencijah (Uradni list RS, št. 52/02), Zakon o inšpekcijskem nadzoru (Uradni list RS, št. 56/02), Zakon o javnih uslužbencih (Uradni list RS, št. 56/02) in Zakon o sistemu plač v javnem sektorju (Uradni list RS, št. 56/02). Poleg tega so bili sprejeti ali novelirani še zakon o lokalni samoupravi, zakon o splošnem upravnem postopku, zakon o elektronskem poslovanju in elektronskem podpisu, zakon o javnih skladih, zakon o upravnih taksah idr. ter sprejetih

24 "For one thing, the Union imposes on its Members obligations expressed in terms of results to be achieved (obligation de resultat)."

25 Med konkretnimi primeri je lahko izpostavimo področje varne hrane (angl. food safety), kjer je Evropska komisija zaradi občutljivosti področja in prepletenosti nalog med več koordinatorji $v$ bistvu terjala formalizacijo sodelovanja med njimi, čeprav gre za tipično vprašanje notranjega pravnega reda Republike Slovenije. Rezultat notranjih in zunanjih usklajevanj je bila tako junija 2003 izdana Uredba o koordinaciji delovanja ministrstev in njihovih organov $v$ sestavi, s pristojnostmi na področju varnosti hrane oziroma živil, pri vključevanju $v$ proces analize tveganja (Uradni list RS, št. 56/03), ki opredeljuje naloge in odgovornost Ministrstva za zdravje, Ministrstva za kmetijstvo, gozdarstvo in prehrano, Ministrstva za okolje, prostor in energijo oz. na ravni organov $v$ sestavi Zdravstvenega inšpektorata RS, Urada RS za kemikalije, Uprave RS za varstvo pred sevanji, Veterinarske uprave RS, Inšpektorata RS za kmetijstvo, gozdarstvo, lovstvo in ribištvo, Inšpektorata RS za kontrolo kakovosti kmetijskih pridelkov in živil, Inšpektorata RS za okolje, prostor in energijo in Uprave RS za varstvo rastlin in semenarstvo.

26 Pri oblikovanju strateških smernic in konkretnih ukrepov reforme slovenske uprave so bile večkrat vključene mednarodne izkušnje, a $v$ omejenem obsegu. Tako npr. izkušnja pri pripravi zakona o javnih agencijah, ko naj bi uporabili primerjalno pravno analizo agencij $v$ državah OECD za določitev sistema regulatornih agencij pri nas, a je bil na koncu sprejet edini možni zaključek, da enostavnega prenosa v sistemskih vprašanjih ni. Velja načelo "razumeti in upoštevati, ne prepisovati" (nem. kapieren, nicht kopieren). 
vrsta neregulatornih ukrepov ${ }^{27}$. Izpostaviti velja še Zakon o dostopu do informacij javnega značaja (Uradni list RS, št. 24/03)), ki operacionalizira načelo odprtosti.

Poleg zakonodajnih ukrepov je treba v luči nanizanih načel in standardov EUP poudariti aktivnosti $v$ sklopu programa odprave administrativnih ovir, ki se je začel izvajati pomladi 2001 in je dosegel nekaj spodbudnih uspehov (npr. odprava ugotovitvene odločbe za izpolnjevanje pogojev kot pogoj za registracijo gospodarskih subjektov, prenos bremena pridobivanja podatkov iz uradnih evidenc s strank na organe javne uprave); enako velja za e-upravo (npr. portal upravnih enot s katalogom življenjskih situacij). Veliko truda je bilo vloženega pri spodbujanju in upravljanju kakovosti v slovenski upravi, tako prek standardizacije minimalnih dobrih praks poslovanja s strankami ${ }^{\mathbf{2}}$, kot prek standardov zagotavljanja kakovosti (slovenskim upravnim organom je bilo podeljenih okoli 30 ISO certifikatov) in uporabe modelov (predvsem CAF je uporabilo okoli 30 organov, do konca leta 2003 naj bi jih še približno 10; načrtuje se (pilotno) kandidaturo za Priznanje RS za poslovno odličnost).

Zadnja podfaza reforme slovenske uprave se formalno začenja z julija 2003 sprejeto vladno Strategijo nadaljnjega razvoja slovenskega javnega sektorja 20032005. Ta s predpisi EU ni neposredno povezana, a upošteva skupna načela EUP in posamezne evropske standarde, kot je CAF. Nadalje strategija v poglavjih o optimizaciji, standardizaciji in informatizaciji poslovnih procesov ter upravljanju kadrovskih virov upošteva priporočila SIGMA (1998) za Slovenijo, kjer so bile kot pomanjkljivosti izpostavljene:

1. slaba medministrska koordinacija,

2. reaktivna kadrovska politika in

3. skrb za sposobnost implementacije novo sprejete zakonodaje.

Koordinacija naj bi bila izboljšana z reorganizacijo vladnega sektorja (ministrstev, organov v sestavi, vladnih služb, upravnih enot) in oblikovanjem tipologije horizontalnim upravnih procesov. Kadrovsko politiko ureja Zakon o javnih uslužbencih, ki vnaša proaktivne elemente upravljanja kadrovskih virov. Implementacijske dejavnosti delimo $v$ tri skupine: sprejem podzakonskih predpisov, usposabljanje za izvajanje novih zakonov in upravni nadzor.

$27 \mathrm{~V}$ razvojnem procesu je medsebojno povezanih več dimenzij spreminjanja uprave - funkcionalna, organizacijska, upravljavska (glede kadrov, financ, IT idr.), procesna. Slovenska uprava je bila reformirana predvsem glede organizacijskih struktur in načinov upravljanja virov, medtem ko procesni vidik ni bil $v$ ospredju. To ni presenetljivo, če si predočimo dejstvo, da uprava deluje kot monopolna dejavnost $s$ ciljem varovanja javnega interesa, zato je $v$ izogib zlorabi oblasti zanjo značilna velika stopnja regulacije. Posledično je tudi reforma uprave - vsaj v delu, ki določa njene naloge in strukturo - nujno predvsem normativnega značaja. Kljub temu kritiki reforme slovenske uprave med drugim navajajo (pre)veliko naravnanost reforme na regulativo. Ti je treba pritrditi, da zgolj sprejemanje novih predpisov ni garancija za napredek, zato bo treba večjo pozornost $v$ prihodnje nameniti implementaciji nove zakonodaje in načel EUP z različnimi tipi ukrepov.

28 Uredba o načinu poslovanja organov javne uprave s strankami (Uradni list RS, št. 22/01, 81/03). 


\section{Polonca Kovač}

\section{Evropski upravni prostor - realnost ali mit}

Trendi razvoja slovenske javne uprave so postali v slabem desetletju vsebinsko in metodološko povsem skladni s trenutnimi prizadevanji držav članic EU. To dokazuje zadnje srečanje ministrov in generalnih direktorjev za javno upravo $v$ državah članicah EU, junija 2003 na Rodosu, katerega zaključna resolucija poudarja pomen širjenja idej kakovosti, stalnega ocenjevanja in izboljševanja ter izmenjave najboljših praks upravnega dela (na temelju modela CAF oz. sorodnih orodij), stalnega usposabljanja in izpopolnjevanja, posodobitve premestitev javnih uslužbencev izven državnih meja, projektov $v$ sklopu informatizacije uprave, zlasti portalov za uporabnike, izboljšanja regulative in spodbujanja socialnega partnerstva.

\section{Prihodnost evropskega upravnega prostora}

Če si skušamo predočiti prihodnost EUP, se moramo najprej vprašati, od kod našo pot začenjamo, torej - do katere stopnje je EUP zaživel $v$ praksi evropskih uprav. Pri tem se je treba zavedati, kot opozarja Demmke v Bugarič (2003, str. 29), da se sicer skupna načela dostikrat zelo različno uporabljajo $v$ različnih nacionalnih kontekstih, saj pravna načela zaradi svoje splošnosti dopuščajo znotraj opredelitve posameznega pojma več mogočih interpretacij. Pollitt (2001) ugotavlja, da povsod po svetu obstajajo ključne razlike med načrti in izvedbeno ravnjo, hkrati se pri izvajajočih se reformah določena področja ne vključi v splošno politiko, npr. proračunske reforme, sistem javnih uslužbencev, upravne postopke. Omenjena avtorja zato za novi javni menedžment in EUP predlagata uporabo koncepta različnih konvergenc oz. združevanj: 1 - diskurzivna konvergenca pomeni, da vse več ljudi govori o istih konceptih, 2 - konvergenca pri odločitvah pomeni, da država/lokalne skupnosti dejansko sprejemajo isto/podobno obliko in tehniko odločitev, 3 - praktična konvergenca, ki pomeni, da javni sektor dejansko začne delovati na podoben način, in končno najteže dosegljiva 4 - konvergenca rezultatov, o kateri lahko govorimo, če imajo reforme enake/podobne rezultate oz. učinke.

Če uporabimo navedene range konvergenc za pregled realizacije elementov EUP po posameznih vsebinskih področjih, ugotovimo, da je prva stopnja diskurzivne konvergence dosežena povsod, saj se na različnih srečanjih in konferencah razpravlja o skorajda vsem. Oblastne odločitve so v posameznih državah že bistveno različne, najbolj glede decentralizacije in proračuna kot klasičnih nacionalnih domen, torej na področjih javnih financ, lokalne samouprave in privatizacije oz. kontraktualizacije. Za posamezne institute oz. projekte, če že ne za celotni področji, lahko ugotovimo praktično konvergenco pri upravljanju kadrovskih virov in e-upravi. Nedvomno pa lahko o konvergenci rezultatov govorimo kvečjemu pri upravljanju kakovosti v (evropski) upravi. Slednje izhaja ne le iz uporabe istih modelov (ki so jih nenazadnje že oblikovali predstavniki posameznih uprav, kar stopnjo njihove uporabljivosti in 
legitimnosti enormno poveča), temveč predvsem iz zavedanja, da je uporaba teh modelov le orodje za načrtovanje in izvajanje istih ukrepov. Praktično konvergenco pri kakovosti lahko utemeljimo z rezultati primerjanj in pretokom dobrih praks, npr. vzpostavitev urada vse na enem mestu (angl. one-stop-shop). Da bi opredelili konvergenco rezultatov pri kakovosti, lahko $v$ tem trenutku uporabimo le šesti čut, saj ustreznih metodologij ugotavljanja učinkov reform ni na voljo. Vsekakor bi morali ugotavljati zakonitost dela, uspešnost in učinkovitost ter odprtost oz. konkretneje npr. trajanje postopkov, dostopnost uprave (lokacijsko in časovno, elektronsko poslovanje), strokovnost, prijaznost in ustrežljivost uslužbencev ipd.

Kljub odprtim vprašanjem večina avtorjev izraža up v nadaljnji razvoj EUP, vsaj kot ene izmed oblik evropeizacije javnih uprav. $\vee$ tem okviru lahko evropeizacijo razumemo tudi kot odpravo nekaterih posameznih administrativnih ovir, ki onemogočajo večjo konkurenčnost in posledično večjo kakovost upravnih storitev ${ }^{29}$. Kot poudarja Brezovšek (2003. str. 82-83), kljub vsemu zaradi evropeizacije ne glede na spremembe $\vee$ kvaliteti in kvantiteti državne oblasti ne bo prišlo do odprave države in uprave.

Ko razmišljamo o prihodnosti, se moramo zavedati, da zaradi kontingenčnosti družbenih procesov, t. j. odvisnosti njihovega poteka in posledic od družbenih, ekonomskih in političnih okoliščin, $v$ katerih se odvijajo, njihovega natančnega razvoja ni mogoče predvideti (Brezovšek, 2003, str. 76). EUP vsekakor je tak družbeni proces, zato bo intenziteta njegovega razvoja in predvsem udejanja $\vee$ praksi posledica politične volje vladajočih koalicij, ekonomskih možnosti posameznih držav in EU kot celote ter nenazadnje zahtev uporabnikov javne uprave. Za spodbudo razvoja EUP bodo nedvomno aktualne zlasti tiste silnice, ki so botrovale njegovemu nastanku, to so skupni pravni red, skupna valuta, enotni gospodarski prostor s temeljnimi svoboščinami prostega pretoka blaga, storitev, delovne sile in kapitala, interakcije na osebni ravni, skupni modeli kakovosti idr. Zaradi različne moči teh silnic, bodo posamezna področja EUP napredovala različno hitro. Uporabljali se bodo različni tipi ukrepov, med katerimi je pričakovati predvsem deregulacijo in neregulatorne dejavnosti. Zaradi takega pristopa bodo še bolj kot sicer $v$ ospredju optimizacija upravnih procesov, menedžment kakovosti, sodobne metode upravljanja javnih uslužbencev in operacionalizacija načela odprtosti uprave napram državljanom oz. zainteresirani javnosti.

Z vidika legitimne vloge oblastnikov in upravičenosti porabe proračunskih sredstev velja posebej poudariti pomen transparentnosti delovanja uprave. Javnost delovanja prek sprotnega informiranja je pogoj tako za pridobitev podpore pri vladnih odločitvah, kot za splošno in individualno odgovornost javnih uslužbencev.

29 Zadnja pripravljajoča se novela slovenskega Zakona o splošnem upravnem postopku (Uradni list RS, št. 80/99, 70/00, 52/02) naj bi med drugim uvedla odpravo krajevne pristojnosti za nekatere skrajšane upravne postopke, kjer to omogoča tehnološka oprema (centralni registri podatkov). 


\section{Polonca Kovač}

\section{Evropski upravni prostor - realnost ali mit}

Odprta uprava v tem pogledu obsega več korakov - od informiranja javnosti, do njenega sodelovanja in končno soodločanja pri sprejemanju in izvajanju javnih politik. Pravi test EUP kot realnosti ali mita bo tako preizkus idej, ukrepov in njihovih učinkov $v$ splošni javnosti. Ko bodo predstavniki uporabnikov javnih storitev in civilne družbe začutili, da jim EUP prinaša konkretne koristi (ali bremena), bo $v$ hipu završalo, vrstile se bodo razprave, argumenti za in proti, kar bo samo potrdilo pravo usmerjenost uprave $\mathrm{k}$ ljudem kot nasprotje klasičnega larpurlatističnega delovanja uprave same zase. In odziv javnosti bo končno merilo demokratičnosti Evrope ${ }^{\mathbf{3 0}}$, na kar se EUP vseskozi sklicuje.

\section{Sklepne misli}

Če povzamemo, pomeni Evropski upravni prostor skupek temeljnih načel in minimalnih standardov upravnega dela, ki stremijo $k$ učinkovitemu izvajanju acquisa, a so $v$ veliki meri za konkretno uporabo bodisi preveč abstraktni bodisi neaplikatibilni za individualne državne rede. Zato so dimenzije EUP v več segmentih le mrtve črke na papirju. Najbolj obetajoče je področje upravljanja kakovosti, ki se z geografsko in medsektorsko globalizacijo čedalje bolj uveljavlja $\vee$ EU in širše kot enotna javna politika ${ }^{\mathbf{3 1}}$. O dejanskem pomenu EUP pa ne bodo odločali akademiki, politiki, javni uslužbenci in zunanji svetovalci, temveč prej ali slej zainteresirana javnost. EUP ne sme biti cilj evropske integracije, temveč mehanizem njenega optimalnega učinkovanja na uporabnike storitev evropskih javnih uprav.

\section{Literatura in viri}

- Bossaert, Danielle, Demmke, Christoph: Civil Services in the Accession States - New Trends and the Impact of the Integration Process, European Institute of Public Administration, Maastricht.

- $\quad$ Brezovšek, Marjan, Haček, Miro (ur.) (2003): Globalizacija in državna uprava, Fakulteta za družbene vede, Ljubljana.

- Bugarič, Bojan (2003): Evropeizacija državne uprave: vpliv evropskega prava na državno upravo držav članic, zbornik, X. Dnevi javne uprave, Fakulteta za upravo, str. 23-35.

- Caddy, Joanne, Vintar, Mirko (ur.) (2002): Building Better Quality Administration for the Public: Case Studies from Central and Eastern Europe, NISPAcee, Bratislava.

30 Tako tudi Weiler meri demokratičnost EU, ki naj bi se dokazala kot dejanska entiteta šele s premikom javnosti od ravnodušnosti k soodločanju (2003, str. 32).

31 Strokovnjaki po svetu tudi $v$ tem niso enotnega mnenja, tako npr. $v$ vabilu potsdamske univerze na konferenco o EUP organizatorji nasprotno ugotovitvam tega prispevka izrecno poudarjajo tezo, da so strategije izboljševanja kakovosti $v$ upravi po državah zelo različne, saj naj bi zadovoljstvo uporabnikov in njihovi standardi temeljili na politični in upravni tradiciji posameznih držav. 


\section{Evropski upravni prostor - realnost ali mit}

- Cardona, Francisco (2001): Assessing Horizontal Administrative Systems in CEE Countries Candidate to the EU, Seminar on Strengthening the Administrative Capacity for the Implementation of Acquis", 18. - 19. 9. 2001, Vilna.

- Engel, Christian (2003): Quality Management Tools in CEE Candidate Countries - Current Practice, Needs and Expectations, European Institute of Public Administration, Maastricht.

- European Principles for Public Administration (1999), Sigma Papers No. 27, OECD, Pariz.

- Falconer, Peter K. (1997): Javna uprava in novi javni management: izkušnje iz Velike Britanije, zbornik, IV. Dnevi slovenske uprave, VUŠ, Ljubljana, str. 52-67.

- Ferfila, Bogomil (ur.), Kovač, Polonca, Žurga, Gordana, Klinar, Igor, Plaznik, Aneta (2002): Ekonomski vidiki javne uprave, Fakulteta za družbene vede, Ljubljana.

- Flynn, Norman, Strehl, Franz (ur.) (1996): Public Sector Management in Europe, Prentice Hall.

- $\quad$ http://efqm.org, dobljeno 7. 10. 2003.

- $\quad$ http://www.eipa.nl/CAF, dobljeno 7. 10. 2003.

- $\quad$ http://www.mnz.si/Urad za organizacijo in razvoj uprave, dobljeno 7. 10. 2003.

- Ivanc, Blaž (2003): Teoretični in praktični vidiki evropskega upravnega prava, IX. Dnevi javnega prava, zbornik, Inštitut za javno upravo pri Pravni fakulteti, Ljubljana.

- Kerševan, Erik (1998): Primerjalni pregled sistemov javnih uslužbencev in posameznih institutov, ki urejajo njihov položaj, Javna uprava, let. 34, št. 4, str. 655-676.

- Kovač, Polona (2003): Quality Management Tools in Slovenian Public Administration: From ISO to CAF and Forward, 1st International Quality Conference in Public Administration, Conference Proceedings, Bratislava.

- $\quad$ Pirnat, Rajko (1999): Neodvisne upravne institucije, Javna uprava, let. 35, št. 3.

- Pollitt, Christopher (2001): 20 Years of Public Management Reform - What Have We Learned and What Have We Forgotten? v Conference 20 Years of Public Management Reform Which Ways Forward?, Maastricht 6.-7.12.2001.

- Preparing Public Administrations for the European Administrative Space (1998), Sigma Papers No. 23, OECD, Pariz.

- Skupni ocenjevalni okvir za organizacije v javnem sektorju (CAF) - Kako s samoocenjevanjem izboljšati organizacijo (2003), Ministrstvo za notranje zadeve - Urad za organizacijo in razvoj uprave, Ljubljana.

- Strategija nadaljnjega razvoja slovenskega javnega sektorja 2003 - 2005 (2003), Vlada Republike Slovenije, Ljubljana.

- The European Administrative Space: Governance in Diversity (2002), invitation, EGPA Annual Conference, University of Potsdam.

- Weiler, Joseph H. H. (2002): Ustava Evrope: "Ali nova oblačila imajo cesarja" in druge razprave o evropski integraciji, Pravna fakulteta Univerze v Ljubljani, Ljubljana.

Mag. Polonca Kovač je diplomirala na Pravni fakulteti, nato leta 1999 magistrirala na Fakulteti za družbene vede. Sprva se je zaposlila na Upravni enoti Kranj, leta 1996 pa na Ministrstvu za notranje zadeve, kjer se je ukvarjala z reformo slovenske javne uprave, strukturo državne uprave in razvojem kakovosti v upravi. Od leta 2002 je zaposlena na Fakulteti za upravo kot asistentka na področju upravnih postopkov. Je avtorica vrste člankov. 
Polonca Kovač

Evropski upravni prostor - realnost ali mit

\section{SUMMARY}

\section{European Administrative Space - the Reality or the Myth}

The European Administrative Space (EAS) is the informal acquis communautaire in the field of public administration, which has been developed by SIGMA experts in late nineties due to the enlargement of European Union. It sets minimal standards for candidate countries on the issue of the reform of political institutions and public administration (especially central administration). Furthermore so-called European principles of administrative law have been developed on the basis of the decisions of the European Court of Justice: reliability and predictability (legal certainty), openness and transparency, accountability, efficiency and effectiveness. These standards and principles, coming into the force via common political, economic and societal development in Europe, are not obligatory directly but represent a political criterion for candidate countries.

Despite the common basis of the EAS there are some critical views of the phenomenon, arising from open questions such as: what is the definition of public sector and public administration, where are the boundaries of the EAS, is the underlying entity public administration as set of organizational, procedural and managerial elements or administrative law, to what extent can we talk about "European" public administration, what is the relation (if any) among the EAS, the Good Governance theory and New Public Management etc.

Nevertheless the EAS is incorporating common principles and measures on the fields of Quality Management, e-government, Human Resource Management and Civil Service System, public finances, local governance, para-governmental organizations etc.

Quality Management incentives in Europe are based on intensive work of Innovative Public Services Group who developed and disseminated European Common Assessment Framework (CAF), based on excellence model EFOM but specifically designed for organizations within public sector. The CAF is a tool to be used to detect major organizational deficiencies and furthermore to prepare and implement an action plan for better work. More than some hundred organizations Europe wide have assessed themselves from 2000, so the next step is definitely the development of benchmarking database to promote exchange of good practices. It is also of great importance to continue with organization of European quality conferences (OC - 2000 Lisbon, 2002 Copenhagen, 2004 Rotterdam) to harmonize and unify the understanding of 
wording "Quality in European Public Administrations". The EAS has developed some criteria on the field of Civil Service System as well, focusing on the employment, training, promotion, salaries and social security of officials. The key principles are professionalism, political neutrality, objectivity and ethics. The candidate countries are supposed to pass special Civil Service Act. The field of informatisation is dedicated to redesign and standardize business processes in administration and to increase accessibility of administration. The principle of Results Oriented Budgeting is in the center of modern public finances system. Local self-government has to gain some crucial functions and finance to carry out them properly. It has to develop participation of citizens and professionalism within its employees. There is also a recommendation put for countries to pass the national law to set rules for establishment of independent non-governmental organizations.

Slovenia has followed all the standards and principles described during its own public administration reform which has been strengthened from 1997 due to the process of the accession to EU. The requirement of the EAS has been to develop national administrative capacity to effectively implement acquis, therefore to establish or adjust institutions to carry out the tasks to be set by acquis in certain administrative fields. SIGMA annual peer reviews focused its research on legality and impartiality of civil servants, criteria for decision-making in administrative procedures to be set in advance, management and supervision over public funds. Slovene public administration reform was so far implemented in four periods: firstly after the establishment of independent state, secondly within EU integration, thirdly from 2002-2003 when majority of new laws were passed and lately with the very new governmental strategy on further development of Slovene public sector 2003 to 2005. From the EAS perspective the great challenge was overcome by new legislation from 2002 such as State Administration Act, Inspection Supervision Act, Public Agencies Act, Civil Service Act, Act on Wage System in the Public Sector etc. Furthermore special governmental programme of removal of administrative barriers was passed in 2001 and some successful measures on the field of e-government have been introduced. Many organizations have developed its own Quality Management systems through ISO standards and by use of CAF model. Nevertheless Slovenia still has to make efforts regarding inter-ministerial coordination and poor Human Resource Management. The final point is to implement the new legislation by passing secondary legislation, training of civil servants and internal supervision. Despite some deficiencies mentioned Slovenia has its place in the circle of modern European public administrations. 
Polonca Kovač

Evropski upravni prostor - realnost ali mit

To check whether there is some hope to actually develop the idea of the EAS in practice we have to analyze to what extent the process of the europesation of public administrations has been successful so far. Is there the convergence or divergence in place? If we follow the concept of different convergences proposed by C. Pollit and C. Demmke, only the Quality Management is standardized in actual activities and possibly impacts across the Europe as a common policy.

The EAS is therefore a set of principles and standards, not (yet) fully implemented as such in Member States and Candidate Countries since it is interpreted differently in specific national circumstances. The possible exception is Quality Management in European public administrations. But it will not be the officials, politicians or consultants to decide what is the actual meaning of the EAS, the answer is to be given by users of public services when interested enough. 